DOI: 10.19085/journal.sijmd021103

\title{
Impact Of Union Budget On Indian Stock Market
}

\author{
Dr. Divya Verma Gakhar \\ Assistant Professor at USMS, GGSIPU, New Delhi, India.
}

Ms. Neha Kushwaha

Student at USMS, GGSIPU, New Delhi, India.

Ms. Vinita Ashok

Student at USMS, GGSIPU, New Delhi, India.

oScholedge International Journal of Management \& Development (ISSN 2394-3378), Vol.02, Issue 11 (2015) p21-36. Published by: Scholedge R\&D Center [www.theSCHOLEDGE.org] [Email: sijmd@scholedge.org]

\section{ABSTRACT}

This paper analyzes the impact of Union budget on NSE's CNX NIFTY Index. The impact is measured in terms of daily average returns and volatility over the short term, medium term and long term period in pre and post budget period. The data has been collected for five budget periods from 2011 to 2015. The statistical tools used are paired T-test and F-test. Paired T-test is conducted on average returns and F-test is conducted on variances over the period i.e., 3, 10 and 30 days in pre and post budget period. The maximum impact of budget is seen in short term then it gradually decreases in medium term and finally diminishes in the long term. The implication of this paper is that the investor should fear from investing in the stock market around the budget period.

Keywords: CNX Nifty, Union Budget, Volatility/ Variances, NIFTY Returns, Pre-budget period and Post-budget period

\section{INTRODUCTION}

There is a relationship between economic performance of a nation and its financial markets performance. In developing economies like India, stock market tends to perform better than economies with lesser growth rate. The stock market generally reflects the economic conditions of a country.When an economy grows, its output increases which leads to increase in profitability of firms. Higher the profits, the company shares become more attractive and stock market shows an upward trend in prices. The Union Budget has an impact on the economy and financial market of the country. It is perhaps the most-watched event in formulating economic policies in India. 
An important source of forecasting economic growth of the country and understanding government policies is the fiscal policy of a country, which is presented in the form of Annual budget. According to the Article 112 of the constitution, the union budget is an annual financial statement of the estimated revenues and expenditures of the government for a fiscal year; which runs from 1st April to 31st March. It is an important tool for the government to sustainably use its scarce economic resources and the government announces its plan for the next financial year. The policies regarding taxation like the change in rates for different commodities and services, the expenditure to be made in different sectors, the decisions regarding the change in monetary policy etc. are taken in the budget. The budget has two parts: one part of budget is an economic survey that gives all the figures on government spending and income, and the remaining part of it, tells what the government intend to do in the coming year.

Causal empiricism reveals that the stock market activity also tends to be greatly influenced by Budget. The stock market response is often viewed as an information on the 'quality' of Budget announced, in terms of improving macro-economic prospects. The information in the budget about the different sectors affect the stock prices of the companies listed on the stock exchanges.

The present study analyses the reaction of stock market on the budget announcement. The previous researches suggest that immediate response can be considered important after the budget announcement and markets can also be given some time to digest the information. In the light of this effect, budget impact has been studied on 3 days (short term), 10 days (medium term) and 30 days (long term). In the paper, we have studied the impact of budget on CNX NIFTY. CNX Nifty Index represents about $66.85 \%$ of the free float market capitalization of the stocks listed on NSE and represents 23 sectors of the market.

The study will help investors to invest cautiously and act as guidance on their investment decision around the budget period. The investors are able to understand volatility in the market due to announcement of Budget in a particular financial year. It helps the investors to minimize their overall risk and maximize returns of their investment during this period.

This paper has been divided into five sections: section one introduces the topic, section two reviews the literature, section three discusses methodology of the study, section four analyses the results and section five concludes the paper.

\section{LITERATURE REVIEW}


Various authors have studied different aspects of investor's reaction on stock market. Some researches try to establish day of the week and calendar effect on movements in stock market.

Sharma (2006) examined calendar effects during the post reform era in the Indian stock market. the study concluded that the Indian stock market exhibited some seasonality in daily returns over the period January 1, 1996 to August 10, 2002. The major findings are the Monday-Tuesday, MondayFriday, and Wednesday-Friday sets have positive deviations for all the indices. Jayen B. Patel (2008) found in their study, two distinct calendar effects in returns, for the Indian stock market. A November-December effect in which mean returns for November and December were significantly greater than those of the other ten months and a March-to-May effect in which mean returns for the months March to May are significantly less than those during the other nine months. Dash et al. (2011) found that month-of-the-year effect in Indian stock markets is positive for November, August and December effects, and a negative March effect. The study also suggests that the incidence of market crashes reduces these seasonal effects.

Some other researchers have tried to map investor behavior on specific industry or policy effects of the government. Chakradhara (2008) observed the nature of relationship and the direction of causality between interest rates and stock prices in India for the period from April 1996 to June 2006. He found that there is a long run relationship between interest rates and stock prices. The long-term interest rates are found to affect stock prices negatively, whereas short-term interest rates affect stock prices positively. De Bondt and Thaler (1985) investigated whether people tend to overreact to unexpected and dramatic events and thus affect stock price movements. The study emphasized that investors overreact and push stock prices to extreme ends on both sides and that the market may be efficient in the short run but not in the long run. Mohanty (2004) examined the stock price reaction to announcement of various policy issues by Government of India. The study covered the three industries, viz. the telecom sector, the banking and financing sector and the pharmaceutical sector. He used the event study methodology to assess the speed and accuracy of stock price reaction to public announcement. The results show that the stocks generally react to public news quite quickly, but the first adjustment is not always the correct one. There is also a mild evidence of presence of learning lag. In another study, Sabnavis (2005) examined the effect of various economic events, natural disasters and political disturbances on Sensex, for the period 1991 to 2005. The study also captured the turnaround time for each of the events. Economic events and natural disasters were not found to have much impact on the Sensex movements. However political events like resignation of Prime Minister or attack on parliament had more effect on Sensex. But, in all the cases, except after Babri Mosque demolition in 1992, the markets were found to recover within next few days only. 
Kaur (2004) studied month effect in Indian stock market. They did not find a January effect in the Indian stock market, but did find that March and September generated substantially lower returns, whereas February and December generated substantial positive returns, concluding that February was one of the most volatile months when compared to April and March, in both the cases of NSE \& BSE. This, she presumed, was due to the announcement of budget in that month.

Very few studies in India have taken place on the impact of Union budget announcement on Indian stock market, as it is an importance policy decision of the government. Rao (1997) during the period from 1991 to 1995, it was found that budget contributed to the volatility in stock prices.

Thomas and Shah (2002) analysed the Indian stock market index from April 1979 to June 2001 covering 26 Budget dates in this period and finds that in some years, post-budget returns are positive; in other years post-budget returns are negative; on average, there is no clear pattern about movement in the Index after budget date. They report no evidence of over-reaction or underreaction prior to Budget date, or immediately after it. Thus concludes that the information processing by stock market participants is rational, and that the Indian stock market is semi-strong efficient.

Kaur (2004), the study found out that February was one of the most volatile months when compared to April and March, both in cases of NSE \& BSE. This, she presumed, was due to the announcement of budget in that month.

Dimensional Securities (2005) observed that Sensex has significantly given negative returns during the post-budget period as compared to a pre-budget time period. The same has been reported in seven occasions in the last 15 years. The study covered all the budgets, presented during the period from 1990 to 2004.

Gupta and Kundu (2006) analyzed the impact of Union Budget on stock market considering the returns and volatility in Sensex. They found that budget have maximum impact in short-term postbudget period, as compared to medium term and long term average returns and volatility does not generally increase in a post-budget situation as the time period increases.

Varadharajan and Vikkraman (2011) studied volatility of four major indices of Indian stock market and the effect of budget on the volatility of stock market from 2002-2011. They found that it is during the 
post budget, volatility in the stock market is higher in comparison to pre-budget. Return of the indices post-budget is negative when compared to pre-budget. Month of May showed highest volatility followed by October and March showed high volatility. SENSEX and BSE 100 have higher standard deviation as compared to NIFTY and NIFTY JUNIOR in yearly analysis of the indices.

Kutchu(2012) analyses semi-strong efficiency of Indian stock market. The study states the effect of union budget on six selected sectoral indices. The results of the study showed that there is a chance to make abnormal returns by the investor. In light of the results, it seems to be inconclusive evidence about overall impact of budget either on the stock market or on a particular sector, but the results seem to point in the direction that the effect of the Budget may be company-specific.

S.Babu and Dr. M.venkateswara (2013) analysed the impact of Union Budgets on Indian stock prices. The period for the study was from 1991 to 2009 and findings say that budgets seem to have effect only up to fifteen trading days from the budget day as far as return is concerned. So investor must be very careful and very swift while investing just around and on the budget day. The authors also reported that a budget exerts the maximum impact in terms of absolute return immediately on and around the budget day which gradually gets reduced as one moves further away from the budget day.

Singhvi (2014),examined the impact of union budgets of index NIFTY of NSE in terms of returns and impact of announcements of union budget on the pre-budget period and post-budget period and have found that budget day returns are more than the returns during the previous 30, 15, and 3 trading days. There is no significant impact of union budget on the average returns provided by Nifty in short term(3), medium term(10) and long term(15) period.

\section{Research Methodology}


The study analyses the impact of budget on Indian stock market CNX NIFTY Index. The sub objectives of the study include the following:

- To analyse the effect of announcement of budget on NIFTY returns in the pre-budget and post- budget period.

- To analyse and compare the volatility i.e. variance of daily returns in the stock market (CNX NIFTY) for short term (3 days), medium term (10 days) \& long term (30 days) in pre-budget and post-budget period.

The following hypotheses have been framed:

$\mathrm{H}_{\mathrm{o}}$ : There is no significant impact of budget on NIFTY returns.

$\mathrm{H}_{1}$ : The difference in the volatility when comparing all the post budget periods with long term pre budget period for Nifty Index, is insignificant.

$\mathrm{H}_{2}$ : Volatility in short term period ( 3 days) is more than medium (10 days) \& long term period (30 days) during post-budget session.

The daily closing prices of NIFTY index have been collected from the NSE website for a period from 2011 to 2015 which includes a total of 5 Union Budgets and 1 Interim Budget. The time period of the study has been classified into pre-budget and post budget period. A total of 60 trading days' data around the budget period has been taken. The event window is divided into short term ( 3 days), medium term (10 days), long term (30 days) before and after the declaration of the union budget.

The secondary data have been analysed using the following statistical tools:

- First, the logarithmic daily returns have been found over the previous day's closing value during the entire 5 year period.

- Second, the average returns in pre-budget and post-budget period, during the previous and the next 3,10 and 30 days are calculated.

The Return is calculated using logarithmic method as follows.

$\mathrm{Rt}=\log (\mathrm{Pt} / \mathrm{Pt}-1)$

$\mathrm{Rt}=$ Market return at the period $\mathrm{t}$

$\mathrm{Pt}=$ Closing Price of index at day $\mathrm{t}$

Pt-1 =Closing Price of index at day $\mathrm{t}-1$

$\log =$ Natural log

- Third, the standard deviation and variances during the previous and next 3,10,and 30 days of the budget is calculated. 
- After this, the statistical tools, a paired T-test using SPSS have been applied on average returns.

- F-test has been applied over the variability of returns of CNX NIFTY over different periods.

The test statistic $\mathrm{F}$ is calculated as follows:

$$
\mathrm{F}=\sigma\left(\mathrm{X}_{1}\right)^{2} / \sigma\left(\mathrm{Y}_{1}\right)^{2},
$$

$$
\text { Where: } \begin{aligned}
& \sigma\left(X_{1}\right)^{2}=\sum\left(R_{x 1}-R_{X_{1}}\right)^{2} /\left(n_{1}-1\right) \\
& \sigma\left(Y_{1}\right)^{2=} \sum\left(R_{y 1}-R_{y 1}\right)^{2} /\left(n_{2}-1\right)
\end{aligned}
$$

Here, $X_{1}, Y_{1}$ are two sample time periods, and $\sigma\left(X_{1}\right)^{2}$ and $\sigma\left(Y_{1}\right)^{2}$ being the sample return variances and $\mathrm{n}_{1}$ and $\mathrm{n}_{2}$ being their respective number of observations.

PERIOD OF STUDY

\begin{tabular}{|l|l|l|l|l|l|l|}
\hline PREVIOUS & PREVIOUS & PREVIOUS & $\begin{array}{l}\text { BUDGET- } \\
\text { DAY }\end{array}$ & NEXT & NEXT & NEXT \\
\hline 30 days & 10 days & 3 days & Day-end & 3 days & 10 days & 30 days \\
$\left(X_{3}\right)$ & $\left(X_{2}\right)$ & $\left(X_{1}\right)$ & $(Z)$ & $\left(Y_{1}\right)$ & $\left(Y_{2}\right)$ & $\left(Y_{3}\right)$ \\
\hline
\end{tabular}

Two set of hypothesis tests will be conducted in this part of analysis:

- In the first set, variances of returns during the short-term, medium-term and long-term periods in the post-budget situation have been compared to one another, i.e., variances of returns between $Y_{1}$ and $Y_{2}, Y_{2}$ and $Y_{3}$ and $Y_{1}$ and $Y_{3}$ respectively have been examined. These comparisons have been made because variances are expected to rise with the increasing time-period. The null hypothesis in all the three tests assume no change in variance i.e. variances are equal.

- In the second set, each of the post-budget short-term, medium-term and long-term periods have been compared to the long-term pre-budget period, i.e, variances of returns between $X_{3}$ and $Y_{1}, X_{3}$ and $Y_{2}$ and $X_{3}$ and $Y_{3}$ respectively have been examined into. These tests have been framed with a more empirically established fact that the variances in returns after budget are expected to be greater than the pre-budget long-term variance. 


\section{ANAYLSIS AND DISCUSSION}

Table 1 represents the average daily returns given by CNX NIFTY during various periods around the budget. The estimates indicate that an individual budget has maximum impact (positive or negative) in the short-term(3 days post budget),which diminishes in the medium-term(10 days post budget) and further reduces in the long-term (30 days post budget) in comparison to the pre-budget period.

Table 1: AVERAGE RTEURNS OF CNX NIFTY

\begin{tabular}{|c|c|c|c|c|c|c|}
\hline YEARS & $\begin{array}{c}\text { PRE } 30 \text { DAYS } \\
\left(\mathrm{X}_{3}\right)\end{array}$ & $\begin{array}{c}\text { PRE } 10 \text { DAYS } \\
\left(X_{2}\right)\end{array}$ & $\begin{array}{c}\text { PRE } 3 \text { DAYS } \\
(\mathrm{X} 1)\end{array}$ & $\begin{array}{c}\text { POST } 3 \\
\text { DAYS } \\
\left(Y_{1}\right)\end{array}$ & $\begin{array}{c}\text { POST } 10 \\
\text { DAYS } \\
\left(Y_{2}\right)\end{array}$ & $\begin{array}{c}\text { POST } 30 \\
\text { DAYS } \\
\left(Y_{3}\right)\end{array}$ \\
\hline 2015 & 0.00235 & 0.00196 & 0.00396 & 0.00220 & -0.00220 & -0.00129 \\
\hline 2014(INTERIM) & -0.00072 & -0.00024 & 0.00044 & 0.00178 & -0.00024 & 0.00340 \\
\hline 2014(UNION) & 0.00103 & 0.00002 & -0.00600 & -0.00193 & 0.00290 & 0.00134 \\
\hline 2013 & -0.00170 & -0.00375 & -0.00681 & -0.00055 & 0.00174 & -0.00130 \\
\hline 2012 & 0.00050 & -0.00037 & -0.00195 & -0.00072 & -0.00145 & -0.00080 \\
\hline 2011 & -0.00244 & 0.00040 & -0.00629 & 0.01085 & 0.00247 & 0.00350 \\
\hline
\end{tabular}

In the short-term there are three cases of positive post-budget returns in 2015, 2014(interim), 2011 and two cases of positive returns during the pre-budget period in 2015, 2014 (interim).In medium term, there are three cases of positive post-budget returns in 2014(union), 2013, 2011 in comparison to three cases of positive returns during the pre-budget period in 2015, 2014(union), 2011. In case of long-term budget effect, there are three cases of positive returns post-budget in 2014(interim), 2014(union), 2011 and three cases of pre-budget returns in 2015, 2014(union), 2012. The above observations have been further corroborated by statistical evidences.

In 2014 (interim budget) pre-budget period, the average daily returns were very low in long- term period (-0.00072) as compared to medium (-0.00024) and short- term (0.00044). Post- budget period, the returns increased in short term (0.00178), became negative in medium-term (-0.00024) 
and then positive (0.00340) in long-term. This shows that though the interim budget was good enough, but the budget was not impactful for the overall economy in long-run.

In 2014 (union budget), as there was a change in the government of the country, and budget was made in the favour of investors. The announcements made in the Budget were positive, e.g. The increase in investment limits in FDI (foreign direct investment) announced were favourable for the economy. The long term returns in pre- budget and post- budget period were almost same and the budget didn't have a major impact on the returns. This shows that budget have no significant effect in the long run.

In 2015, pre-budget period, in short term the returns were higher than medium term, and long term have higher returns than medium term. Post- budget period, the returns became negative in medium term and long term as compared to short- term i.e. short term have higher returns than medium and long term. This was the first time; the new government has presented the budget so they have brought a very moderate budget to bring the economy back on the track for development. A base was made to support the economy growth in the country. The results show that budget do not have significant impact in long run. 
Paired Samples Statistics

\begin{tabular}{|c|c|c|c|c|}
\hline & Mean & $\mathrm{N}$ & Std. Deviation & $\begin{array}{c}\text { Std. Error } \\
\text { Mean }\end{array}$ \\
\hline $\begin{array}{c}\text { Pair 1 } \begin{array}{c}\text { Last 30 } \\
\text { days } \\
\text { days }\end{array} \\
\begin{array}{c}\text { Last 10 } \\
\text { days }\end{array}\end{array}$ & $-1.6333333 \mathrm{E}-4$ & 6 & .00179083 & .00073110 \\
\hline $\begin{array}{c}\text { Next 10 } \\
\text { days } \\
\text { Last 3 } \\
\text { days }\end{array}$ & $-2.7750000 \mathrm{E}-3$ & 6 & .00436839 & .00178339 \\
\hline Pair 1 & .0005367 & 6 & .00213591 & .00087198 \\
\hline $\begin{array}{c}\text { Next 3 } \\
\text { days }\end{array}$ & .0019383 & 6 & .00464185 & .00018952419 \\
\hline
\end{tabular}

Paired Samples Correlations

\begin{tabular}{|c|c|c|c|c|}
\hline & & $\mathrm{N}$ & Correlation & Sig. \\
\hline Pair & Last 30 \& next 30 days & 6 & -.495 & .319 \\
\hline Pair & Last 10 days & 6 & -.406 & .425 \\
\hline$\&$ & Next 10 days & & & \\
\hline Pair & Last 3 \& next 3 days & 6 & -.096 & .856 \\
\hline
\end{tabular}

Paired Samples Test

\begin{tabular}{|c|c|c|c|c|c|c|c|c|}
\hline & \multicolumn{5}{|c|}{ Paired Differences } & \multirow[b]{3}{*}{$\mathrm{t}$} & \multirow[b]{3}{*}{ Df } & \multirow{3}{*}{$\begin{array}{c}\text { Sig. } \\
(2- \\
\text { tailed) }\end{array}$} \\
\hline & \multirow[b]{2}{*}{ Mean } & \multirow{2}{*}{$\begin{array}{c}\text { Std. } \\
\text { Deviation }\end{array}$} & \multirow{2}{*}{$\begin{array}{c}\text { Std. Error } \\
\text { Mean }\end{array}$} & \multicolumn{2}{|c|}{$\begin{array}{c}95 \% \text { Confidence Interval } \\
\text { of the Difference }\end{array}$} & & & \\
\hline & & & & Lower & Upper & & & \\
\hline Pair Last 30 & & & & & & & & \\
\hline $\begin{array}{l}1 \quad \& \text { next } \\
30 \text { days }\end{array}$ & $-9.71666667 \mathrm{E}-4$ & .00351536 & .00143514 & -.00466081 & .00271748 & -.677 & 5 & .528 \\
\hline
\end{tabular}


Paired Samples Test

\begin{tabular}{|c|c|c|c|c|c|c|c|c|}
\hline & \multicolumn{5}{|c|}{ Paired Differences } & \multirow[b]{3}{*}{$\mathrm{t}$} & \multirow{3}{*}{\multicolumn{2}{|c|}{ Df tailed }} \\
\hline & \multirow[b]{2}{*}{ Mean } & \multirow{2}{*}{$\begin{array}{c}\text { Std. } \\
\text { Deviation }\end{array}$} & \multirow{2}{*}{$\begin{array}{c}\text { Std. Error } \\
\text { Mean }\end{array}$} & \multicolumn{2}{|c|}{$\begin{array}{c}95 \% \text { Confidence Interval } \\
\text { of the Difference }\end{array}$} & & & \\
\hline & & & & Lower & Upper & & & \\
\hline $\begin{array}{c}\text { Pair Last } 10 \\
1 \text { days \& } \\
\text { next } 10 \\
\text { days }\end{array}$ & $-8.66666667 \mathrm{E}-4$ & .00336704 & .00137459 & -.00440016 & .00266682 & -.630 & 5 & .556 \\
\hline $\begin{array}{cc}\text { Pair } & \text { Last } 3 \\
1 & \text { days- } \\
& \text { next } 3 \\
& \text { days }\end{array}$ & $-4.71333333 \mathrm{E}-3$ & .00667301 & .00272424 & -.01171623 & .00228956 & -1.730 & 5 & .144 \\
\hline
\end{tabular}

\section{DAYS}

A paired sample $t$ test has been conducted to evaluate whether a statistically significant difference exist between the returns of 30 days pre-budget and post-budget period. The result of the paired sample $t$ test were not significant, $t(5)=0.677, p>0.05$, indicating that there is a significant increase in the returns from the pre budget period $(M=1.633, S D=0.00179, N=6)$ to the post-budget period $(M=0.00080, S D=0.00226)$. The mean increase was 9.71 , with the $95 \%$ confidence interval for the difference between the means from 0.0027 to -0.00466 . The research retained the null hypothesis. The analysis has accepted the null hypothesis Ho, so there is no impact of budget on the returns of long term period in CNX NIFTY.

\section{DAYS}

A paired sample $t$ test has been conducted to evaluate whether a statistically significant difference exist between the returns of 10 days pre-budget and post-budget period. The result of the paired sample $t$ test were not significant, $t(5)=0.630, p>0.05$, indicating that there is a significant increase in the returns from the pre budget $\operatorname{period}(M=-3.30, S D=0.0018, N=6)$ to the post-budget period $(M=.0005, S D=.0021)$. The mean increase was 8.666 , with the $95 \%$ confidence interval for the difference between the means of .00266 to -0.00440 . The research retained the null hypothesis.

There is no significant impact of budget on the returns of medium term period in CNX NIFTY as the analysis has accepted the null hypothesis Ho. 


\section{DAYS}

A paired sample $t$ test has been conducted to evaluate whether a statistically significant difference exist between the returns of 3 Days pre-budget and post-budget period in CNX NIFTY returns. The result of the paired sample $t$ test were not significant, $t(5)=1.730, \quad p>0.05$, indicating that there is a significant increase in the returns from the pre budget period $(M=2.775, S D=0.0043, N=6)$ to the post-budget period $(M=0.00193, S D=0.00464)$. The mean increase was 4.7133 , with the $95 \%$ confidence interval for the difference between the means of 0.002289 to -0.01171 . The research retained the null hypothesis.

The null hypothesis Ho has been accepted by the research so there is no significant impact of budget on the returns in short term period of CNX NIFTY.

Table 2 : VARIANCES OF RETURNS

\begin{tabular}{|c|c|c|c|c|c|c|}
\hline YEAR & $\begin{array}{c}\text { PRE 30 } \\
\text { DAYS } \\
(\mathrm{X} 3)\end{array}$ & $\begin{array}{c}\text { PRE 10 DAYS } \\
(\mathrm{X} 2)\end{array}$ & $\begin{array}{c}\text { PRE 3 } \\
\text { DAYS } \\
(\mathrm{X} 1)\end{array}$ & $\begin{array}{c}\text { POST 3 } \\
\text { DAYS } \\
(\mathrm{Y} 1)\end{array}$ & $\begin{array}{c}\text { POST 10 DAYS } \\
(\mathrm{Y} 2)\end{array}$ & $\begin{array}{c}\text { POST 30 } \\
\text { DAYS } \\
(\mathrm{Y} 3)\end{array}$ \\
\hline 2015 & 0.00008 & 0.00007 & 0.00014 & 0.00005 & 0.00009 & 0.00009 \\
\hline $2014($ INTERIM) & 0.00006 & 0.00005 & 0.00009 & 0.00007 & 0.00005 & 0.00004 \\
\hline $2014(\mathrm{UNION})$ & 0.00008 & 0.00010 & 0.00012 & 0.00010 & 0.00006 & 0.00006 \\
\hline 2013 & 0.00004 & 0.00008 & 0.00015 & 0.00019 & 0.00011 & 0.00009 \\
\hline 2012 & 0.00013 & 0.00014 & 0.00019 & 0.00019 & 0.00023 & 0.00012 \\
\hline 2011 & 0.00018 & 0.00025 & 0.00034 & 0.00026 & 0.00021 & 0.00014 \\
\hline
\end{tabular}

Table 2 represents the variance of returns in CNX NIFTY. A cursory glance at it shows decreased volatility over the long term compared to the medium term and short term in pre-budget period and also a decreased volatility over the long term compared to the medium term and the short term in post-budget period in most of the cases. It implies that volatility \& its impact always reduces as we look forward to the long term.

Table 3: F-test Results Comparing Variance Among the Returns (Post-Budget) with One Another 


\begin{tabular}{|c|c|c|c|c|c|c|c|c|c|}
\hline YEAR & $\begin{array}{c}\text { ACTUA } \\
\text { L } \\
\text { VALUE } \\
\text { S }\end{array}$ & $\begin{array}{l}\text { T.V. } \\
(1 \%)\end{array}$ & $\begin{array}{l}\text { T.V. } \\
(5 \%)\end{array}$ & $\begin{array}{l}\text { ACTUAL } \\
\text { VALUES }\end{array}$ & $\begin{array}{l}\text { T.V. } \\
(1 \%)\end{array}$ & $\begin{array}{l}\text { T.V. } \\
(5 \%)\end{array}$ & $\begin{array}{l}\text { ACTUAL } \\
\text { VALUES }\end{array}$ & $\begin{array}{l}\text { T.V. } \\
(1 \%)\end{array}$ & $\begin{array}{l}\text { T.V. } \\
(5 \%)\end{array}$ \\
\hline & $Y_{1} \& Y_{2}$ & $\begin{array}{c}\mathrm{df}=9 / \\
2\end{array}$ & $d f=9 / 2$ & $Y_{2} \& Y_{3}$ & $\begin{array}{c}\mathrm{df}=2 \\
9 / 9\end{array}$ & $d f=29 / 9$ & $Y_{3} \& Y_{1}$ & $\begin{array}{c}\mathrm{df}=29 / \\
2\end{array}$ & $d f=29 / 2$ \\
\hline 2015 & 1.80 & 99.39 & 19.39 & 1.00 & 3.09 & 2.22 & 1.80 & 99.47 & 19.46 \\
\hline $\begin{array}{c}\text { 2014(interim } \\
\text { ) }\end{array}$ & 1.40 & 8.02 & 4.26 & 1.25 & 3.09 & 2.22 & 1.75 & 5.42 & $3 \cdot 33$ \\
\hline 2014(union) & 1.67 & 8.02 & 4.26 & 1.00 & 3.09 & 2.22 & 1.67 & 5.42 & 3.33 \\
\hline 2013 & 1.72 & 8.02 & 4.26 & 1.22 & 3.09 & 2.22 & 2.11 & 5.42 & 3.33 \\
\hline 2012 & 1.21 & 99.39 & 19.39 & 1.92 & 3.09 & 2.22 & 1.58 & 5.42 & 3.33 \\
\hline 2011 & 1.24 & 8.02 & 4.26 & 1.50 & 3.09 & 2.22 & 1.86 & 5.42 & 3.33 \\
\hline
\end{tabular}

Note: Table Values(T.V) have been sourced fromwww.statsoft.com/Textbook/sttable.html

These findings have been further statistically tested by F-test. Table 3 reveals F-test values for the test that compare the variance among the returns during short-term, medium-term and long-term period after the budget with one another. All the results are non-significant which shows that volatility does not generally increase in a post-budget situation as time period increases. As volatility in short-term period is more than medium \& long term period during post-budget session, so this test have retained the $\mathrm{H}_{2}$ hypothesis.

Table 4: F-test Results Comparing Variance Among the Returns During Post-Budget Periods with Long-Term Pre-Budget Period

\begin{tabular}{|c|c|c|c|c|c|c|c|c|c|}
\hline YEAR & $\begin{array}{c}\text { ACTU } \\
\text { AL } \\
\text { VALUE } \\
\text { S }\end{array}$ & $\begin{array}{l}\text { T.V. } \\
(1 \%)\end{array}$ & $\begin{array}{l}\text { T.V. } \\
\text { (5\%) }\end{array}$ & $\begin{array}{l}\text { ACTUAL } \\
\text { VALUES }\end{array}$ & $\begin{array}{l}\text { T.V. } \\
(1 \%)\end{array}$ & $\begin{array}{l}\text { T.V. } \\
\text { (5\%) }\end{array}$ & $\begin{array}{c}\text { ACTUA } \\
\mathbf{L} \\
\text { VALUES }\end{array}$ & $\begin{array}{l}\text { T.V. } \\
\text { (1\%) }\end{array}$ & $\begin{array}{l}\text { T.V. } \\
(5 \%)\end{array}$ \\
\hline & $X_{3} \& Y_{1}$ & $\begin{array}{c}d f= \\
29 / 2\end{array}$ & $\begin{array}{l}\mathrm{df}= \\
29 / 2\end{array}$ & $X_{3} \& Y_{2}$ & $\begin{array}{c}\mathbf{d f}=\mathbf{2 9} \\
/ 9\end{array}$ & $\begin{array}{c}\mathbf{d f}=29 / \\
9\end{array}$ & $X_{3} \& Y_{3}$ & $\begin{array}{c}\mathrm{df}=29 / \\
29\end{array}$ & $\begin{array}{c}\mathrm{df}=29 / \\
29\end{array}$ \\
\hline 2015 & 1.60 & 99.47 & 4.26 & 1.13 & 3.09 & 2.86 & 1.13 & 2.41 & 3.33 \\
\hline 2014(interim) & 1.17 & 5.42 & 4.26 & 1.20 & 4.65 & 2.86 & 1.50 & 2.41 & 3.33 \\
\hline 2014(union) & 1.25 & 5.42 & 4.26 & 1.33 & 4.65 & 2.22 & 1.33 & 2.41 & 3.33 \\
\hline
\end{tabular}




\begin{tabular}{|c|c|c|c|c|c|c|c|c|c|}
\hline 2013 & $4.75^{*}$ & 5.42 & 4.26 & $2.75^{*}$ & 3.09 & 2.22 & 2.25 & 2.41 & 3.33 \\
\hline 2012 & 1.46 & 5.42 & 4.26 & 1.78 & 3.09 & 2.22 & 1.08 & 2.41 & 3.33 \\
\hline 2011 & 1.44 & 5.42 & 4.26 & 1.17 & 3.09 & 2.22 & 1.29 & 2.41 & 3.33 \\
\hline
\end{tabular}

* $\mathrm{H}_{1}$ is rejected and its alternative is accepted at 5 percent level only.

Table 4 shows specifically the F-test values that compares the variances of returns during short-term, medium-term and long-term post budget periods with that of the long-term pre-budget period. In the short-term period we can see that 2013 budget has significant difference as actual value of $\mathrm{X}_{3}$ and $Y_{1}$ is greater than the table value at 5 percent i.e. 4.75 (actual value) is greater than 4.26 (at 5 percent). The medium-term period in 2013, shows significant difference in post budget medium term \& pre-budget long term values. So, $\mathrm{H}_{1}$ is rejected at 5 percent level only for 2013.

It indicates that in 2013 short term and medium term period after the budget were more volatile when compared to similar long term period before the budget. The results are not significant for other years that shows the volatility does not generally increase after budget.

So this test has retained the $\mathrm{H} 1$ hypotheses as there is no significant difference among the volatility in post budget periods when compared to long term pre budget period.

\section{CONCLUSION}

The results show that budget does not have a significant impact on the CNX NIFTY. After using the paired T- Test, we found that the impact of budget on average returns is not significant whether in pre or post budget period, for short term, medium term \& long term.

The results of F-Test on the variances of returns reveal that short term and medium term period were more volatile than the long term period when compared to similar long term period before the budget, in just one case, but mainly there is no significant difference. So this proves our $\mathrm{H} 1$ hypotheses correct.

It was also seen that the budget has more effect in short term, less in medium term and it diminishes in the long term after the budget announcement retaining the $\mathrm{H}_{2}$ hypothesis. 
So, the investors should invest more cautiously around the budget day as volatility in the market is high in short term during the budget announcement days. As a speculator by making investment strategies one can earn extra profits during this time. For the government and regulators, when markets are more volatile they should monitor the market movements on a real time basis and take corrective measures.

There is a scope to carry on further research in this area by doing sector wise impact of budget. Finally it can be concluded that in the Indian scenario in last five years budget had some impact in the short run but no impact of budget is seen in the medium term and long term

\section{REFERENCES}

- Singhvi, Abha (2014). Impact of Union Budget on NIFTY. Pacific Business Review International, Volume 6, Issue 12.

- Chakradhara, Panda (2008). Do Interest Rates Matter for Stock Markets? Economic \& Political Weekly, Volume 43, 17, 107-115.

- Dash, Mihir, Sabharwal, Mohit and Dutta, Anirban (2011). Seasonality and Market Crashes in Indian Stock Markets. Retrieved from the online research paper publication website: http://ssrn.com/abstract $=178511.2$

- De, Bondt Werner, and Thaler, Richard (1985). Does the Stock Market Overreact? The Journal of Finance, Volume 40, 3, 793-805.

- Gupta, Arindam, and Kundu, Debashis (2006). A Study of the Impact of Union Budgets on Stock Prices in India. The ICFAI Journal of Applied Finance, Volume 12, 10, 65-76

- Patel, Jayen B. (2008). Calendar Effects in the Indian Stock Markets. International Business \& Economics Research Journal, Volume 7, 3

- Kaur, Harvinder (2004). Stock Market Volatility in India. The Indian Journal of Commerce, Volume 57, 4, 55-70.

- Mohanty, Munmun (2004). Stock Market Reaction to Announcement of Policy Changes. The ICFAI Journal of Applied Finance, 34-42.

- Sabnavis (2005). How Sensitive is the Stock Market. Newspaper reference- Business Standard, August 22.

- Babu, S.Suresh and Venkateswarlu (2013). Impact of Union Budget on Indian Stock Prices. International Journal Of Management Research And Review, Article No-7/28902896 Issn: 2249-7196, Volume 3, Issue 5 
- Sharma, Shefali and Singh, Balwinder (2006). Determinants of Equity Share Prices in the Indian Corporate Sector. The ICFAI Journal of Applied Finance, Volume 12, 4,21-31

- Thomas, Susan, and Shah, Ajay (2002). Stock Market Response to Union Budget. Economic and Political Weekly, February, 455-458

- Kutchu, Vishal (2012). Testing Semi-Strong Efficiency of Indian Stock Market - A Study on Effect of Union Budget 2012 on Six Select Sectoral Stocks. International Refereed Research Journal, Volume III, 3(2), 74

- Varadharajan and Vikkraman (2011). Impact of Pre and Post Budget on stock market volatility between 2001 to 2011. Journal of contemporary research in management.

WEBSITES:

www.investopedia.com

www.livemint.com

www.statsoft.com

www.nseindia.com 